\title{
KAS KEELEPOLIITIKA UURIMISE KESKMES PEAKS OLEMA RIIK?
}

\author{
KADRI KOREINIK, MAARJA SIINER, KARA BROWN
}

\section{Pragmaatiline algus?}

$\mathrm{K}$

eelepoliitika kui ühiskonnas keeli normaliseeriv, aga ka hierarhiseeriv tegevusvaldkond arenes välja XX sajandi pragmaatilisest vajadusest ehitada pärast ilmasõdasid ning impeeriumide lagunemist üles rahvusriigid. Kuigi lõviosas Euroopa rahvusriikides kõneldi mitut keelt, tekkisid need enamasti ühe keele baasil. Ühiskondlikku mitmekeelsust korraldavatest keeleteadlastest said koos majandus- ja õigusteadlastega olulised ühiskonda kujundavad sotsiaalsed arhitektid (Jernudd, Das Gupta 1971). Aegamööda kujunes keelepoliitilist ja -korralduslikku tegevust uuriv ja kriitiliselt hindav eraldi teadusharu. ${ }^{1}$ Uurijate hulgas süvenes arusaam keelekasutuse kujundamise keerukusest, sest riiklik, tihtipeale instrumentaalne keelekäsitlus ei arvestanud keelekasutajate muid vajadusi. Teose „Planning Language, Planning Inequality” („Korraldades keelt, korraldades ebavõrdsust”, Tollefson 1991) ilmumine pani aluse keelepoliitika kriitilisele uurimissuunale, mis nihutas tähelepanu keelelt keele kasutajatele ja muutuvale keelekasutuskontekstile. Uurimisvaldkonna paradigmaatilist nihet pole põhjustanud mitte niivõrd muutuv keel, kuivõrd inimeste muutuv eluolu, mida omakorda kujundab muuhulgas kommunikatsioonitehnoloogia areng (Tollefson, PérezMilans 2017). Nüüdsed kesksed teemad on neoliberalismi ja üleilmastumise tuules toimuv ingliskeelestumine ja keelekasutust mõjutav meediastumine (nt Androutsopoulus 2014; May 2015).

Ent Eestis toimusid kaks protsessi, rahvusriigi (taas)ülesehitamine ning avatud majandusest ja kommunikatsioonitehnoloogiast tulenev üleilmastumine, peaaegu samal ajal. Nõnda domineeris äsja taasiseseisvunud, liberaalse turumajandusega riigis konservatiivne (riiklik) keelepoliitika, mille peaeesmärgiks oli riigikeele, st eesti ühis- ja normikeele (vrd kirjakeel) edendamine ja selle kasutusvaldkondade kaitsmine. Riiklikule keelepoliitikale pakub uusi väljakutseid süvenev inglise keele kasutamine, nt rahvusvahelistuvates kõrgkoolides. Taas on kasvanud vene keele tähtsus teenindus-, aga ka avaliku sektori asutuste veebilehtede ametliku keelena (Berezkina 2017). Nendel puhkudel on tegemist nii keelepoliitika varjatumate toimemehhanismide kui ka keele kaubastumise (ingl commodification) näidetega. Peavooludiskursuses sõnastatakse venekeelse vähemuse lõimumine endiselt Eesti peamise „probleemina”, mida riik saab lahendada. Põgusamat tähelepanu on pööratud muudele muutustele keelte staatuses ja kasutuses, kuid olukord, kus ollakse üha rohkem sõltuvad

${ }^{1}$ Uurimisvaldkonna nimetusena kasutatakse sageli mõistet keelepoliitika ja -korraldus (ingl language policy and planning, LPP), mille kohta kasutame rööpselt ka keelepoliitika mõistet. 
teistest inimestest, kellega puudub ühine keel, vajab valdkondadeülest, ehk koguni senisest normatiivsemat käsitlemist (vrd Peled jt 2014).

Artikli ajendiks on vajadus pöörata rohkem tähelepanu keelepoliitika analüüsi keerukusele, sest keelepoliitikate tagajärjed on sotsiaalsed ja sotsiaalmajanduslike muutuste mõju on ühtlasi keelepoliitiline. Peame vajalikuks eemalduda Eesti keelepoliitika uurimise nõukogudejärgsusest ja Baltikumikesksusest. Esmalt piiritleme kesksed mõisted keelepoliitika käsitlemiseks, seejärel vaatleme viimase veerandsajandi Eesti keelepoliitika uurimise fookusi. Lõpuks proovime vastata Lenore Grenoble’i (2017) küsimusele Nõukogude Liidu (NL) ja nõukogude(aegsete) poliitikate mõjust Eesti keelepoliitikale.

\section{Keel, poliitika ja riik}

Sõjajärgne keelepoliitika ja -korraldus, mis toetus 1960. aastatel Noam Chomskyst alguse saanud universaalse grammatika otsingutele keeleteaduses, muutus keelepoliitilise analüüsi jaoks peagi kitsaks, sest keelt peeti kasutajast võrdlemisi autonoomseks süsteemiks. Alates Joshua Fishmanist (1974) liigitatakse keelepoliitikauuringud küll sotsiolingvistika alla, kuid epistemoloogiliselt on need järginud ühiskonnateaduste paradigmamuutusi. Et täiendada keelepoliitika sotsiolingvistilisi ja normatiivseid käsitlusi, on endiselt aktuaalne üleskutse uurida keelepoliitikat poliitikateaduste raames (Sonntag, Cardinal 2015). Sestap on keele kõrval tähtsad ka poliitika ja riigi mõisted.

Üldjoontes peetakse keelt inimesele omaseks representatsioonisüsteemiks, koodiks (ressursiks) või tegevuseks (praktikaks), ühtaegu nii indiviidi kui ka kollektiivi omandiks. Koos rahvusriigiga tekkinud riigikeelt on ennekõike vaja olnud kõnelejaskonna keelelise ja mõttelise ühtsuse jaoks; ühtsus omakorda õigustab sellesama keele abil jagatud hüvesid (Busch 2010). Riigija rahvuskeele staatus ei ole keele omadus, vaid riigi poolt seatud prioriteet. Rahvusriik taastoodab ükskeelset haabitust, ${ }^{2}$ mis tähtsustab idealiseeritud, täieliku normikeele ja keeleregistrite pädevusega keelekasutaja ehk emakeelena kõneleja keelt kui normi (Davies 2003). Sellist normi võib olla keelt mitteemakeelena kõnelejal ehk uuskõnelejal, n-ö muukeelsel kõnelejal raske saavutada, mistõttu on muukeelsus koos mitmekeelsusega muutunud omamoodi sotsiaalseks puudeks (Jørgensen 2010: 155). Nõnda toimibki kodanikuühtsuse ja sotsiaalse sidususe teenistuses olev ükskeelne haabitus ilma- ja väljajätu tööriistana, nt takistab ligipääsu haridusele, tööturule ja pidurdab sotsiaalset mobiilsust (Wright 2004).

Teine tuumikkontseptsioon - poliitika - nõuab samuti eraldi selgitamist. Aristoteleslik poliitilisuse kontseptsioon - tegevus- ja kõnevõime - osutab poliitika tekkepõhjusele ja loomulikustab inimese sotsiaalse olemuse (Arendt 1954). Poliitikat (ingl politics) kui antagonistlikku dimensiooni eristatakse inimeste kooseksisteerimist - sh keelelise mitmekesisuse „majutamist” - organiseerivate diskursuste, institutsioonide ja praktikate kogumist. See viimane

${ }^{2}$ Haabitus ehk „habitus on seesugune praktiline meel, mis ütleb meile, mida teha konkreetses olukorras - seesama, mida spordis nimetatakse mänguvaistuks, oskuseks ennetada mängu käiku, mis on mängu hetkeolukorras punktiirina olemas” (Bourdieu 2003 [1977]: 49); vrd mõiste bioloogias. 
on eesti keeles samuti poliitika (ingl policy). Peame poliitikat kompleksseks sotsiokultuuriliseks võimupraktikaks (vrd Shore, Wright 1997). Selline definitsioon arvestab, kuidas võetakse omaks riiklikke poliitikaid, aga sedagi, kuidas nii üksikindiviidid (nt õpetajad, lapsevanemad) kui ka grupid-organisatsioonid teevad oma igapäevaste valikute kaudu keelepoliitikat. Ühtlasi avardab see domineerivat arusaama poliitikast kui (riigi)valitsuse autoritaarsest tööriistast, riiklikust sanktsioonide süsteemist. On oluline hoomata, et keele abil kujundatakse poliitikakontseptsioone ja poliitikad omakorda konstrueerivad keelt (Petrovic 2015). Kuna kõnelejaskond (diskursiivselt) loob ja hoiab keelt oma ühishüvena, võib keelepoliitikat uurida kui diskursust, selleks sobib hästi keelepoliitika uurimise kriitilise suuna meetodivalik (kvalitatiivne, etnograafiline ja diskursusanalüütiline). Kvalitatiivsel lähenemisel ongi olulisim uurija poliitikakäsitlus, sest sellest oleneb, milliseid (uurimis)küsimusi esitatakse, milliseid andmeid kogutakse ning milliseid allikaid ja meetodeid kasutatakse, millised „poliitikatooted” lõpuks kujundatakse (Guba 1984: 63).

Riik on kolmas oluline kontseptsioon. ${ }^{3}$ Riigid kui suured komplekssed organisatsioonid on teataval määral autonoomsed ega peegelda pelgalt ühiskonna sotsiaalsete rühmade huve; ent riigi allorganisatsioonid (nt ministeeriumid ja ametid, üldharidus- ja kõrgkoolid) võivad olla oma huvide taotlemisel autonoomsed (Skocpol 1985). Riik kui legitiimne, suveräänse grupi (rahva) elukorraldust reguleeriv organisatsioon ja domineerimise allikas on olnud lähtepunktiks keelepoliitika uurimissuunale, mis mõistab poliitikat peamiselt riiklike valikutena. Nüüd on mitmetasandilise valitsemise (ingl multilevel governance) uurimine seadnud kahtluse alla tsentralistliku riigi võimekuse allriiklike (perifeersete), sotsiaalsete gruppide (ühiskond) ja kodumaiste ( $v s$. välis-) huvide ainsa legitiimse esindajana (Piattoni 2009). Seegi artikkel vaeb keelepoliitika riigikeskse uurimise enesepiisavust. Kahtlemata ei puudu riigil keelepoliitikas roll: oluline on mõista, millist osa mängivad riigisisesed ja -ülesed toimijad keelepoliitika kujundamisel riigist eraldi, millist koos riigiga.

\section{Miks Eesti?}

Jaan Kaplinski luuletus „Ida ja Lääne piir rändab ikka, vahel itta, vahel läände..." (1985) näitab Eesti liminaalsust (vt ka Kull, Lang 2015). Et piirid „rändavad” ühel või teisel moel, näitas ilmekalt Euroopa Liidu (EL) ja NATO laienemine. Keeleökoloogilises plaanis on minevikus olnud eesti keele kõrval kolm võõrkeelte klastrit, mis peegeldavad piirilolekut, rändemustreid ja vahelduvaid võime (vt Hennoste jt 1999). Need on sajandeid domineerinud koloniaalkeel saksa keel, ajutisemad halduskeeled, nt ladina keel keskajal, rootsi ja vene keel, ning mittedomineerivad väikeste etniliste rühmade keeled. Möödunud sajandil on saksa ja vene keelt koos eesti keelega nimetatud koguni kolmeks kohalikuks keeleks. ${ }^{4}$ Sõltuvalt ajaperioodist on võimud vor-

\footnotetext{
${ }^{3}$ Ingliskeelses erialakirjanduses sobib riigi kõrval kasutada ka mõistet polity, mis hõlmab nii riiki kui ka teisi poliitilisi olemeid, nt Euroopa Liitu.

${ }^{4}$ Paul Ariste kommenteerib trilingvismi 1920. aastate lehekuulutuste põhjal: „[---] võib jääda mulje, et noil kümnenditel oli kolme keele, eesti, saksa ja vene keele tundmine meie linnades ja vahest ehk isegi maal vajalik, kuna tolleaegne Eesti rahvastik võis olla ulatus-
} 
minud prestiižihierarhiaid, mis privilegeerivad keeli nende ulatuse, staatuse ja/või funktsioonide järgi (Liddicoat 2013). Eesti riik on sõdadevahelisel ajal ja taasiseseisvudes püüdnud neid hierarhiaid ümber pöörata. XXI sajandil on inglise keel asunud uusima kohaliku keele positsiooni: Eesti elanikud on koos Põhjamaade naabritega tunnistatud ühtedeks paremini inglise keelt kõnelevateks inimesteks Euroopas. ${ }^{5}$ Osalt on selle taga riigi tahtlik või tahtmatu keelepoliitika, mis kindlustab inglise keele positsiooni esimese võõrkeelena koolis, aga ka de facto kõrghariduskeelena (Soler-Carbonell jt 2017). Seega on eksistentsiaalset hirmu eesti keele kui ainsa riigikeele ja Eesti riigile mõtte andja pärast saatnud ka keeleökoloogiliselt mitmekesine minevik. Väikese keele kõnelejaskonnale tekitab terendav keelevahetus märkimisväärset muret (vt Ehala jt 2014).

Eestit on analüüsitud postkommunistlike muutuste ja üleilmastumise kaksikkontekstist, aga ka postkolonialismist lähtuvalt (Vetik 2012; Annus 2012). Keelepoliitika uurimises ongi dekoloniseerimise ja globaliseerumise protsessid saanud järjest suuremat tähelepanu (Lin, Martin 2005). Eestit on ikka kujutatud siirderiigina: metafoorne „naasmine läände”, kuid ka Euroopasse ja euroopalikuks saamise üleskutse Noor-Eesti programmilistes sõnavõttudes osutavad sihteesmärgile. ${ }^{6}$ Identiteedipoliitikast võib-olla tähtsamgi on riigiidentiteeti loov õiguslik restauratsioon (ingl legal restorationism) ehk ideoloogia, et taasiseseisvunud Eesti ei ole nõukogude vabariigi õiguslik järglane, vaid sõdadevahelise, iseseisva riigi jätkumine (Pettai 2007). Pärast aastakümneid väldanud nõukogude totalitarismi on ellu viidud poliitilisi ja majanduslikke muutusi, mille eesmärk on euroopalike demokraatlike väärtuste, kodanikuühiskonna ja vabaturumajandussuhete taaskehtestamine. Eesti neoliberaalsus ongi poliitiline valik, mis toob kaasa nii majanduskriiside meelevalla (Kattel, Thorhallsson 2013) kui ka avatud maailma mõju keelekasutusele ja -õppele (Klaas-Lang 2016; Hogan-Brun 2017).

Nagu öeldud, võttis Eesti riik, erinevalt neoliberaalsest majanduspoliitikast, kodakondsus- ja keelepoliitika vallas pigem konservatiivse hoiaku. Mööndes radikaalselt erinevate tõlgenduste olemasolu Balti (õiguslike ja poliitiliste) valikute küsimuses, on mitmed uurijad veendunud, et ükskord, kui riigikeelte staatus on taastatud (tehes olematuks nõukogude poolsajandi pärandi), võivad Balti riigid rahumeeli jätkata oma mitmekeelsust toetavaid poliitikaid (Hogan-Brun jt 2007).

\footnotetext{
likult kolmkeelne. Tegelik olukord polnud siiski niisugune [---]. Kolme keelt vajas üksnes piiratud osa elanikke." (Ariste 1969: 140)

${ }^{5}$ Paraku on venekeelsete elanike hulgas võorrkeele, sh inglise keele oskajate osakaal eesti emakeelega elanike omast madalam (Rannut 2017: 200).

${ }^{6}$ Marju Lauristini jt toimetatud artiklikogumikku „Return to the Western World. Cultural and Political Perspectives on the Estonian Post-Communist Transition" arvustades paneb Rein Taagepera (1998) ette, et raamatu pealkiri võinuks sama hästi olla „Return to the Nordic World".
} 


\section{Eesti keelepoliitika uurimise värskem fookus}

Eesti keelepoliitika ja -korralduse uurimises on siiani domineerinud kaks defineerivat kriteeriumi: ajaline määratlus, mis paigutab Eesti p o s t sovetlike riikide hulka, ${ }^{7}$ ning ruumiline või geograafiline määratlus, mis paigutab Eesti Baltimaade hulka ja Euroopasse (EL-i). Varavõitu on öelda, kas Eesti erineb väärtuste (nt suurem ühiskondlik ehk üldistatud usaldus, madalam korruptsioonitajumise indeks) ja rändemustrite (nt viimase paari aasta positiivne rändesaldo) poolest oma ühest või mõlemast Balti naabrist ning paigutub kusagile Ida-Euroopa siirderiikide ja Põhjamaade heaoluühiskonna vahepeale. ${ }^{8}$ Nüüdis-Eesti sotsiaalmajanduslikke probleeme ja ühiskondlikku sidusust on uuritud just nõukogudejärgsuse kontekstis, kus oli loomulik võrrelda Eestit n-ö saatusekaaslaste ehk teiste Balti riikidega. Seda geopoliitilist diskursust on aidanud toita Vene meediaruumis elava venekeelse vähemuse tajumine olulise riikliku julgeolekuteemana ehk Vene ohuna. Pikalt eksisteerinud arusaam, et venekeelsete elanike sotsiaalse lõimumise eeltingimuseks on nende keeleline lõimumine, lõi kõikuma pronksiööjärgse tõdemusega, et erinevused ei piirdu üksnes keelega, vaid ulatuvad lahknevate väärtuste ja ajalookäsitlusteni (Ehala 2009). Kuid fookus on püsinud kuni viimase ajani riiklikul keelepoliitikal ja venekeelse koolihariduse reformidel, kodakondsustemaatikal, aga ka venekeelse meedia rollil (Skerrett 2014; Hogan-Brun, Wright 2013; Vihalemm, Hogan-Brun 2013). Nüüdseks on uurimisfookus aeglaselt nihkunud keeleoskuselt ja keeleliselt lõimumiselt sotsiaalsele sidususele, nt ruumipraktikatele ja ruumilise segregatsiooni küsimustele (Toomet jt 2015), aga ka rändeajastu problemaatikale (vt nt Verschik 2017 ja teised Eesti inimarengu aruande ptk-d).

Terve uurijate plejaad on loonud Baltikumi-keskse keelepoliitika uurimisseisu, kus rõhutatakse Eesti, Läti ja Leedu olulisi ühisomadusi, nt okupeerimiseelselt iseseisvate väikeriikide poliitilist ja sotsiokultuurilist kogemust või Balti kubermangude ühist venestamiskogemust XIX-XX sajandi vahetusel. Seevastu keeletundlikumates uurimisvaldkondades, nt kirjandusteaduses, on Eesti positsioneerimine Balti ruumi kaudu problemaatilisem..$^{9}$ Avardunud horisont ja rändeajastu, aga ka regionaalsed ruumilised ümberjoondumised (nt EL) annavad vihjeid Eesti ees seisvate uute keelepoliitiliste väljakutsete kohta. Toetame Eesti keelepoliitika uurimise aktuaalse ruumilise raamistu-

${ }^{7}$ Ott Kurs eelistab kasutada nimetust „sovetlikud” või „bolševistlikud” ning arvab, et nimetus the former Socialist countries of Central and Eastern Europe on väljapoole Nõukogude impeeriumi piire jäänud saatusekaaslastele ametlikult külge pandud sotsialismi tiitel, mitte nende sisuline iseloomustus (vt Kurs 1998: 628).

8 „Nagu Soome eemaldus pärast Esimest maailmasõda Balti riikidest ja hakkas muutuma Põhjala riigiks, nii toimis pärast taasiseseisvumist ka Eesti, mille kiiret edasiminekut siirdeajal soodustas eelkõige mereline asend ja lähedus kõrgeltarenenud riikidele. Nii kuulubki Eesti majanduslik-kultuurilisse ruumikooslusse, mille keskuseks on kolmnurk Stockholm-Helsingi-Tallinn" (Kurs 1998: 629-630).

${ }^{9} \mathrm{Nt}$ Cornelius Hasselblatt kirjutab: „Nii et ikka kolmpakis, sinna ei olnud midagi parata, ja ajapikku tekkis mul kuri kahtlus, et ma pean kogu ülejäänud elu kulutama sellele, et vabastada vaesed eestlased ahistavast kokkuklammerdatusest teiste Baltimaadega. Töötan selle kallal siiamaani, kusjuures esimene samm on sõna „balti” peaaegu jäägitu kõrvaldamine oma aktiivsest sõnavarast. Kasutan seda sõna veel üksnes keeleteaduslikus mõttes, niisiis juhul, kui vajan ülemmõistet läti, leedu ja vanapreisi keele kohta.” (Hasselblatt 2016: 387) 
sena nii kitsamalt Läänemere piirkonda ${ }^{10}$ kui ka tervet maailma, sest eesti keele kõnelejadki järgnevad majanduslikule heaolule ning kõikidele Eesti ja eestlaste loodud üleilmsetele pere- ja töösidemetele.

Nagu eespool öeldud, ei võimalda postsovetlik raamistus tähele panna märkimisväärset nõukogudeaegset ja -järgset mitmekesisust. Kuigi endised nõukogude liiduvabariigid jagavad ühist poliitilist minevikku ja tänaste keelepoliitikate lähtepunkti, on „Balti kolmiku” puhul tegu kolme erineva sotsiolingvistilise „eksperimendiga” (Pavlenko 2013: 262), mis tulenevalt riikide majanduspoliitilisest ja demograafilisest olukorrast on triivinud riigid nii mõneski keelepoliitilises küsimuses eri suundadesse. Sellisest ajaliselt ja ruumiliselt üsna kitsast määratlusest jääb välja kaugem minevik, nt Eesti ja ka Läti baltisaksa taust. Kaugem ajahorisont võimaldaks vaadelda võimuvahetusest sõltumatuid vastupidavamaid keeleideoloogiaid, mis kajastuvad nt keele ohustatuse diskursuses (vrd Duchêne, Heller 2007). Tõepoolest, keelepoliitika jagamine keelepraktikateks ja keele juhtimiseks (ingl language management) ning keelega seotud uskumusteks (Spolsky 2004) paigutab keelepoliitika kultuuriteaduste naabrusse, sest representeerivad ju domineerivad diskursused (sh narratiivid) seda, mida peetakse keeles ilusaks ja sündsaks või vastupidi, taunimisväärseks. Viimasel ajal on nii meedia kui ka uurijad osutanud just keelepoliitilisest aspektist Eesti laulupeo lõimimispotentsiaalile (vt nt Pawłusz 2017). See põhjustas avalikkuses elavat poleemikat. Kaudselt käsitles viimane laulu- ja tantsupidu „Mina jään” eestlaste väljarände küsimust ja toonitas keele ohustatuse diskursuse uut tahku - keelekadu ei pruugi põhjustada mitte-eestikeelsete sisseränne. Rändega seotud moraalsetele aspektidele on juhtinud mitmes ettekandes tähelepanu antropoloog Aet Annist (nt 2017).

Iga ühiskonda iseloomustab keelepoliitiliste toimijate paljusus, mis näitab keelepoliitika komplekssust ja tsentraalse reguleerimise raskust. Keelepoliitika metafoorina on kujutatud seest siiruviirulist sibulat (vrd Ricento, Hornberger 1996), mille kihtidel, st toimijatel on tihti vastuolulised huvid. Riik sekkub keelepoliitikasse enamasti majandus- või julgeolekupoliitilistel kaalutlustel (Shohamy 2006; McCarty 2011).

\section{Kuidas võim riigi käest pudeneb?}

Üleilmastumise all peetakse silmas tootmise, kaubanduse ja rahaturgude ning tarbimiskultuuri üha hoogustuvat rahvusvahelistumise protsessi, mida tõukab tagant üleilmne võrgustuv telekommunikatsioonisüsteem ja mille abil lõimub maailm kiiresti üheks globaalseks majandusruumiks (Gibson-Graham 2006: 120). Üleilmastumine ahendab rahvusriikide võimalust iseseisvat poliitikat kujundada ja riigi arengut suunata (Saarts 2017). Riigi jõuetuse taustal tõuseb võimsamalt esile avatud turu „nähtamatu käsi”, aga ka hargmaised inimesed ja ettevõtted, marginaliseerides riiki mitmes valdkonnas, k.a keelepoliitikas. Näiteks rahvusvahelistuv kõrgharidus, ülikoolides õppimine ja töötamine, üli-

${ }^{10}$ Läänemere piirkond (maailm) on kasutusel olnud nii ajaloolastel (nt the Baltic World; vt Kirby 1995) kui ka ajalookäsitluste (identiteedipoliitikate) uurijatel, kes mineviku ja oleviku Eesti ruumikonstruktsioone on üksikasjalikult analüüsinud (nt Brüggemann 2003; Pääbo 2014). 
koolide teenindamine, ent paradoksaalselt ka ingliskeelse õppe taunimine stimuleerib teatud keelelisi vajadusi ja seab keelelisi prioriteete (Jenkins 2014).

Üleilmastumist defineeriv joon ja ühtlasi ka teine riiki detsentraliseeriv jõud on riikidevaheline ränne. Inimeste mobiilsus (sh sundväljaränne) ning ideede ja rahaliste vahendite piiriülene liikumine loob uusi, mõnikord hübriidseid identiteete, kujundades samal ajal keelevalikuid. 1991. aasta taasiseseisvumisest peale on Eesti muutunud rände sihtriigina tuntud nõukogude vabariigist peamiselt ida-lääne-suunalise rände lähteriigiks. ${ }^{11}$ Rände mustrid muutusid oluliselt pärast EL-i itta laienemist, eriti pärast seda, kui mitmed vanad liikmesriigid avasid 2006. aastal oma tööturu uutele. Seda, eestlaste kolmandat väljarändelainet on kõrvutatud varasemate massiliste rändeepisoodidega (Tammaru jt 2010). Väljarände tulemusena elab suurim väljaspool Eestit asuv eesti keele kõnelejaskond Soomes, kus nad moodustavad suuruselt teise välispäritolu rühma. Eesti keele kõnelejaskond Soomes on taasiseseisvumisest peale rohkem kui 12 korda kasvanud ning alates tööturu avanemisest enam kui kahekordistunud (StatFin). Viimase Eesti inimarengu aruande (2016/2017) järgi ennustab paari viimase aasta positiivne rändesaldo rändepööret, st Eestist võib kujuneda taas rände sihtriik. ${ }^{12}$ Võib oletada, et mõlema protsessi, sisserände ja väljarändele järgneva tagasirände tulemusena saabuvad ja naasevad Eestisse üha mitmekesisema keeletausta (sh ühise vahendajakeeleta) ja moraalsete tõekspidamistega inimesed. Moraali all peame silmas seda, mida peetakse nt heaks eluks, õigeks keeleks, õiglaseks ühiskonnaks.

Tõsi küll, riikide keelepoliitikad järgnevad keelekasutajatele ka üle riigipiiri (vt hargmaisuspoliitika kohta nt Jakobson 2017). Näiteks toetab Eesti rahvuskaaslaste programmi kaudu (alates 2004. aastast) välismaal elavaid etnilisi eestlasi. Programmi toel vahendatakse infot Eesti ja eestlaste väliskogukondade vahel, soodustatakse välismaal eesti keele hoidu ja oskust, mis võimaldab soovi korral Eestisse naasta. Eesti keele ja kultuuri akadeemilise välisõppe programmi kaudu toetatakse eesti keele õpetamist teiste riikide kõrgkoolides. Ka mitmetel suurriikidel on keelepoliitiliste käepikendustena kultuuri tutvustavad ja keeleõpet toetavad organisatsioonid-võrgustikud (nt Goethe Instituut). Vene valitsuse poolt 2007. aastal loodud sihtasutus Russkiy Mir peaks ühendama Euroopa suurimat (ekstraterritoriaalset) keelerühma vene keele kõnelejaid. Ent mure kaasmaalaste pärast muutus kiiresti tõhusaks välispoliitika ja propaganda vahendiks, õigustades Vene valitsuse sekkumist suure venekeelse vähemusega riikide siseasjadesse. (Ryazanova-Clarke 2014)

Kolmas riiki detsentraliseeriv protsess on regionaliseerumine, mis liidab „enamasti naabruses või omavahel ühenduses olevaid riike, mis on loobunud vabatahtlikult osast oma suveräänsusest kollektiivsete majanduslike püüdluste nimel” (Joffé 2007: xiv). Regionaliseerumine loob riikide kõrvale alternatiivseid võimukeskusi ja survestab paratamatult riikide keelepoliitikat (nt EL-i tööjõu vaba liikumist, õpirännet puudutavate jt keelekasutust mõjutavate poliitikate kaudu), kuid ka loob või tugevdab riigipiire ületavaid sotsiokultuurilisi sidemeid. Et alal hoida ja kultiveerida veel ühte Eesti piire üle-

${ }^{11}$ Viimase veerandsaja aasta jooksul on peamiselt etnilised venelased, ent ka teised Nõukogude Liidu taustaga etnilised rühmad naasnud Eestist oma kodumaale (Anniste 2014).

${ }^{12}$ Viimase rändelaine eestlasi on peetud peamiselt virtuaalkogukonnaks (Eesti inimarengu aruanne 2016/2017). 
tavat sotsiokultuurilist sidet - hõimurahvaid -, tegutseb Eesti riik aktiivselt. Etnolingvistilist riiklusele eelnevat sidet, soome-ugri kontseptsiooni, mida mõne uurija arvates hoiab koos „narratiiv” (Korkut 2008), toetab riiklik hõimurahvaste programm. Tegemist on Eestile olulise piiriülese keele- ja kultuurisuguluse ning identiteediga, mida tutvustas aastail 1989-1997 aktiivne etnofuturistlik liikumine. Selles osalenud loovisikud edendasid põliste identiteetide elavdamise ja väärtustamise ideed ning rajasid teed mitteriiklikule keeleaktivismile ja -poliitikale (Hennoste 2012). Näiteks Kagu-Eesti etnoregionalism on saanud moraalset tuge just etnofuturismist.

Igal juhul näitab rändeajastu, et riigivõimukeskselt määratletud, nt nõukogude, postsovetlik vms keelepoliitika, ei pruugi anda ammendavat seletust keelekasutuse, -korralduse ja -ideoloogiate dünaamikale. Nii nõukogudeaegne kui ka selle järgne vaatenurk, nagu tegelikult iga teinegi võrdlusalus, jätab kõrvale mineviku- ja olevikuprotsesside vahelise keerulise dünaamika (nt identiteedipoliitika). Põhiküsimus seisneb selles, kui kaua veel on võimalik uurida keelepoliitikat postsovetlikult vaateveerult ja kas sellest piisab, et mõista keelesituatsiooni nüüdis-Eestis, kus üleilmastumine ja ränne lahjendavad riigi keelepoliitilist dominanti.

\section{Milline on ikkagi nõukogude aja keelepoliitiline pärand?}

Umbes sellise küsimuse esitab kogumiku „Language Policy Beyond the State” („Keelepoliitika väljaspool riiki”, Siiner jt 2017) epiloogis Lenore Grenoble. Enam kui veerandsaja aasta möödumine Eesti iseseisvuse taastamisest annab hea vaatluspositsiooni ja piisava ajalise distantsi, et uurida, kuidas mõjutas Nõukogude okupatsioon nüüdis-Eesti keelepoliitikat. Selle mõju fookusesse tõstmise kõrval mööngem veel kord, et riik ei ole kaugeltki ainuke keelepoliitika määraja nüüdis-Eestis. Keelepoliitikat, nagu vihjab kogumiku pealkiri, kujundavad nii minevik kui ka tänapäev, sh NL ja EL, aga mis veelgi olulisem, oma ajastul üles kasvanud ja hariduse saanud inimesed. Grenoble’i küsimus väärib ka edaspidi ulatuslikku interdistsiplinaarset analüüsi, kutsub reflekteerima nt EL-i liikmelisuse mõju üle Eesti keelepoliitikale lühemas, nii umbes kümneaastases vaates. Kõik nimetatu osutab keelepoliitika analüüsi komplekssusele: kuidas kindlaks teha, kust keelepoliitika algab ja kus lõpeb, kui ei piirduta vaid avaliku poliitika valdkondadega. Komplekssus tuleneb osalt sellest, millise „võrguga” keelepoliitikat püüdma minna, et hõlmata kõiki keelekasutust kujundavaid, ka varjatud poliitikaid. Üheks näiteks sobib nõukogudeaegne rahvastiku ümberpaigutamine, mille ülesanne oli industrialiseerimist hoogustada ja/või majandust lõimida, kuid mis kujundas ka keelehierarhiaid. Varjatud keelepoliitikaid, mis mõjutavad ja kujundavad keeleõppe võimalusi, kõnelejate kontsentratsiooni, üldisi keelt puudutavaid orientatsioone ja muud, ei varustata keelepoliitika sildiga, neid ei genereerita ega rakendata kui avalikke keelepoliitikaid (vrd Shohamy 2006). Ometi on nende allpool jutuks tulevate nõukogudeaegsete poliitikate, sh residentsus- ja eluasemepoliitika, liikumis- ja reisimispoliitika, haridussüsteemi mõju Eestile pikaajaline.

Esiteks, nõukogudeaegsed poliitikad toimisid kestva mõjuga varjatud keelepoliitikana, sest nii eespool mainitud NL-i plaanimajanduslikust indust- 
rialiseerimispoliitikast tulenev välisränne (NL-i siseränne) kui ka haldusmeetmed (vt nt Light 2010) ja muud linnastumismustrid, sh eestlaste alalinnastumine, viisid uue keeleökoloogiani. Need poliitikad lõid stabiilse, tänini püsiva kõnelejate geograafilise kontsentratsiooni: venekeelse enamusega asustuse Tallinnas ja Kirde-Eestis. ${ }^{13}$ Juba 1970-ndate Eesti oli naabruskonniti, aga ka töökohapõhiselt ja kooliti etnolingvistiliselt segregeeritud (vrd Kährik 2006). Omamoodi paradoksaalne on, et samad asjaolud, mis põhjustasid eestlaste alalinnastumise, lükkasid edasi ka eesti ühiskeelesuunalist keelevahetust ja hoidsid alal lõunaeestikeelset kõnelejaskonda Kagu-Eestis. Ehkki keelevahetus leidis aset kogu XX sajandi jooksul, jäi selle intensiivseim periood just „küpse sotsialismi” aega, kui linnastumine Lõuna-Eestis ja saartel oli kõige kiirem (Tammaru 2001). Linnastumine koos ühtse ja ühtlustava ühiskeelse koolihariduse ning massimeediaga (1950. aastate keskel alustanud televisiooniga) tasandas ühiskeele-võru kakskeelsust kiiremini kui kunagi varem. Kokkuvõtvalt võib öelda, et nõukogude poliitikatega arvestamine kutsub paralleelselt uurima ka tänaseid esmapilgul keelepoliitilise mõjuta trende: valglinnastumist, maaelu arengu riiklikku ja rahvusvahelist toetamist ning „piirideta” (e-)residentsust üle kogu EL-i.

Teiseks toimisid Nõukogude sise- ja välispoliitika samuti kui keelepoliitikad. Kinnine piir viis NL-i ideoloogilisse ja geograafilisse isolatsiooni (Chandler 1998), muutes muuhulgas „välismaa” ja „lääne” tähendust (vt Gorsuch 2011). Suletud piiride tõttu avanes aga nt teadlastel võimalus sõita itta ning uurida välitöödel uurali rahvaid ja nende keelt. Eesti sidemed hõimurahvastega olid alanud juba varem, kuid nõukogudeaegsed reisi- ja akadeemilised piirangud soodustasid eriti (humanitaar)teadlaste võimalusi süvendatult soome-ugri rahvaste keele- ja kultuurieluga tegeleda (Zagreben 2007). Vene keele oskus mängis siin võtmerolli, võimaldades nii välitöid teha kui ka uurimistulemusi avaldada. Kahtlemata aitasid tollased kultuurilised ja empiirilised olud tihendada Eesti kui soome-ugri identiteediga maa diskursust taasiseseisvumisperioodil (Feldman 2000). Niisamuti toimivad Eesti suhtes keelepoliitikana EL-i (kodanike vaba liikumise) poliitikad, mis toetavad õpirännet, teadlas- ja tööalast mobiilsust, kasvatades ühtlasi nõudlust inglise keele oskuse järele.

Kolmandaks, ka tollast haridussüsteemi puudutavad poliitikad funktsioneerisid keelepoliitikana. Koolide de facto jagunemine eesti ja vene õppekeelega asutusteks alusharidusest kuni gümnaasiumiastmeni välja on pärandunud Eestissegi. Lisaks jätkuvale vene õppekeelega koolides toimuvale mittevene õpilaste venestumisele (Rannut, M., Rannut, Ü. 2010; vt ka Aidarov, Drechsler 2013) on praeguseni alles duaalne haridussüsteem, mis on suures kontrastis sõdadevahelise Eesti õppekeelte valikuga. Vene õppekeelega koolis toiminud minimaalse eesti keele õppe ja venekeelse elanikkonna geograafilise kontsentratsiooni tõttu pole kadunud vajadus Eesti riigi poolse võimali-

${ }^{13}$ Etnolingvistiline situatsioon Tallinnas ja Kirde-Eesti linnades on siiski väga erinev: Tallinna eluasemesegregatsioon ei pruugi kirjeldada etniliste rühmade käitumist vabal ajal. Peale selle on Tallinn Eesti peamine turismi-, teenuste ja tõmbekeskus, mille tõttu on eesti ja vene keele kõnelejate de facto osakaal ilmselt erinev registri- ja loenduspõhisest. Narvas ongi kõik keelekeskkonnad venekeelsed: naabruskonnad, töökohad ja vaba aja veetmise paigad. Vt ka domeenide kohta segregatsiooni uurimises nt van Ham, Tammaru 2016. 
kult varajase eesti keele kui teise keele õppe toetamise järele. Ent kui pidada silmas eesti keele homogeniseerumist XX sajandil, on nõukogudeaegsed eesti õppekeelega koolid mänginud olulist rolli teatud keelevõimekuse kustutamisel (ingl erasure) (vrd Irvine, Gal 2000). Nõukogude ja varasemate hariduspoliitikate ja koolipraktikate efektiivsus eesti normikeele edendamisel, kuid ka normi- ja ühiskeelest erinevate keelte (nn murdekeelte) kasutust ja õpet puudutava orientatsiooni kultiveerimine (nii koolis kui ka väljaspool) avaldab mõju ka XXI sajandi koolis.

\section{Coda: muutuv aegruum ja keelepoliitika komplekssus}

Rändeajastul on võimu, ka keelepoliitilise võimu asukohta üha keerulisem määrata. Maiskondliku fookuse avardamine toonitab agentsuse ja ressursside olulisust keelepoliitika uurimisel ning annab parema võimaluse selle mitmekihilisust avastada ja ka analüüsida. Kui keelepoliitikat ja -korraldust uurida koos rahvusloome ja riigiehitamisega, on Eesti ideaalne näide sellest, kuidas on keelepoliitika ja -korralduse kontseptsioon ja rakendamine muutunud. 1980. aastateks vaibusid lääneriikides mitmed sõjajärgsed, n-ö klassikalised keeleprobleeme „lahendavad” keelekorraldustegevused, mis elasid läbi renessansi postsovetlikes maades nagu Eesti. Paraku ilmuvad ka Eesti ette uued, üleilmastumise, liberaalse majanduspoliitika ja EL-iga lõimumisega seotud väljakutsed, mis kombineerudes nõukogudeaegsete ja varasemate olude ja ideedega loovad teatava mittelineaarse rajasõltuvuse. ${ }^{14}$ Seda komplekssust oleks vaja lähemalt uurida, et paremini mõista, kuidas elab eesti keele kasutaja, ja seega, kuidas elab eesti keel.

Artikkel põhineb raamatu „Language Policy Beyond the State” avapeatükil „Introductory Chapter: Questioning Borders” (Siiner jt 2017) ja on avaldatud kirjastuse Springer loal. Artikkel on kirjutatud uurimisteema IUT20-3 „Eesti keele kestlikkus avatud maailmas (EKKAM)” raames.

\section{Kirjandus}

Aid a r ov, Aleksandr, Drech sler, Wolfgang 2013. Estonian russification of ethnic minorities in Estonia? A policy analysis. - Trames, kd 17, nr 2, lk 103-128.

Androuts o p o u lus, Jannis 2014. Mediatization and sociolinguistic change: Key concepts, research traditions, open issues. - Mediatization and Sociolinguistic Change. Toim J. Androutsopoulos. Berlin-Boston: de Gruyter, lk 3-48.

Annist, Aet 2017. Migratsiooni moraalist: eestlaste sunnitud ja sundimatu ränne. - Plenaarettekanne Eesti sotsiaalteaduste X aastakonverentsil: „Eesti 100 - teel avatusele?", 24.-25. märtsil 2017 Tallinna Ülikoolis.

Anniste, Kristi 2014. East-West migration in Europe: The case of Estonia after regaining independence. (Dissertationes Geographicae Universitatis Tartuensis 57.) University of Tartu Press.

14 Autorid tänavad prof Raivo Vetikut mittelineaarse rajasõltuvuse (ingl path dependency, vrd David 1985) mõiste soovitamise eest. 
Annus, Epp 2012. The problem of Soviet colonialism in the Baltics. - Journal of Baltic Studies, kd 43, nr 1, lk 21-45.

Arendt, Hannah 1954. The Human Condition. Chicago: University of Chicago Press.

Ar i s te, Paul 1969. „Kolm kohalikku keelt”. - Keel ja Kirjandus, nr 3, lk 140-147.

B er e zkin a, Maimu 2017. Russian in Estonia's public sector: 'Playing on the borderline' between official policy and real-life needs. - International Journal of Bilingual Education and Bilingualism, kd 20, nr 4, lk 417-427.

B ourdieu, Pierre 2003. Praktilised põhjused. Teoteooriast. Tlk Leena Tomasberg. (Avatud Eesti Raamat.) Tallinn: Tänapäev.

Br üggem a n n, Karsten 2003. Leaving the 'Baltic' states and 'Welcome to Estonia': Re-regionalizing Estonian identity. - European Review of History: Revue européenne d'histoire, kd 10, nr 2, lk 343-360.

B u s ch, Brigitta 2010. New National Languages in Eastern Europe. - Handbook of Language and Globalization. Toim Nikolas Coupland. Oxford: Wiley-Blackwell, lk 182-200.

Chandler, Andrea M. 1998. Institutions of Isolation: Border Controls in the Soviet Union and Its Successor States, 1917-1993. Montréal-Kingston: McGillQueen's University Press.

David, Paul A. 1985. Clio and the Economics of QWERTY. - Papers and Proceedings of the Ninety Seventh Annual Meeting of the American Economic Association (May, 1985). The American Economic Review, kd 75, nr 2, lk 332-337.

Davies, Alan 2003. The Native Speaker: Myth and Reality. Clevedon: Multilingual Matters.

Du chêne, Alexandre, Heller, Monica (toim) 2007. Discourses of Endangerment Ideology and Interest in the Defence of Languages. New York: Bloomsbury Publishing.

Eesti inimarengu aruanne 2016/2017. Eesti rändeajastul. Peatoim Tiit Tammaru. Tallinn: Eesti Koostöö Kogu, 2017. https://inimareng.ee (1. VIII 2017).

Ehala, Martin 2009. The Bronze Soldier: Identity threat and maintenance in Estonia. - Journal of Baltic Studies, kd 40, nr 1, lk 139-158.

Ehala, Martin, Koreinik, Kadri, Praakli, Kristiina, Siiner, Maarja 2014. Kuidas uurida keele kestlikkust? - Keel ja Kirjandus, nr 7, lk 489-508.

Feldman, Gregory 2000. Shifting the perspective on identity discourse in Estonia. - Journal of Baltic Studies, kd 31, nr 4, lk 406-428.

$\mathrm{F}$ is h $\mathrm{m}$ a n, Joshua 1974. Language planning and language planning research: The state of art. - Advances in Language Planning. Toim J. Fishman. The Hague: Mouton, lk 15-35.

Gibson-Graha m, J. K. 2006. A Postcapitalist Politics. Minneapolis: University of Minnesota Press.

Gor s u ch, Anne E. 2011. Soviet Tourism at Home and Abroad After Stalin. Oxford University Press.

Grenoble, Lenore A. 2017. Epilogue. - Language Policy Beyond the State. Toim Maarja Siiner, Kadri Koreinik, Kara D. Brown. Springer, lk 241-245.

$\mathrm{Gub}$ a, Egon G. 1984. The effect of definitions of policy on the nature and outcomes of policy analysis. - Educational Leadership, kd 42, nr 2, lk 63-70.

Hasselblatt, Cornelius 2016. Ma armastasin eestlast. Autobiograafilised retked. Tallinn: Tuum. 
Hennoste, Tiit 2012. Ethnofuturism in Estonia. - International Yearbook of Futurism Studies, kd 2, nr 1, lk 253-285.

Hen nos te, Tiit, Ke ev allik, Leelo, Paju s a lu, Karl 1999. Introduction. - International Journal of the Sociology of Language, kd 139, nr 1, lk 1-16.

H o g a n - B r u n, Gabrielle 2017. Linguanomics. London: Bloomsbury Publishing.

Hogan-Brun, Gabrielle, Ozolins, Uldis, Ramoniene, Meilute, Rannut, Mart 2007. Language policies and practices in the Baltic States. - Current Issues in Language Planning, $\mathrm{kd}$ 8, $\mathrm{nr} 4$, lk 469-631.

Hog a n - Br u n, Gabrielle, Wright, Sue 2013. Language, nation and citizenship: Contrast, conflict and convergence in Estonia's debate with the international community. - Nationalities Papers, kd 41, nr 2, lk 240-258.

Irvin e, Judith T., G a l, Susan 2000. Language ideology and linguistic differentiation. - Regimes of Language: Ideologies, Polities, and Identities. Toim Paul V. Kroskrity. Santa Fe: School of American Research Press, lk 35-84.

Jakobs on, Mari-Liis 2017. Hargmaisuspoliitika. - Eesti inimarengu aruanne 2016/2017. Eesti rändeajastul. Peatoim Tiit Tammaru. Tallinn: Eesti Koostöö Kogu, lk 111-118. https://inimareng.ee (1. VIII 2017).

Jenkins, Jennifer 2014. English as a Lingua Franca in the International University: The Politics of Academic English Language Policy. London: Routledge.

Jernudd, Björn, Das Gupta, Jyotirindra 1971. Towards a theory of language planning. - Can Language Be Planned? Sociolinguistic Theory and Practice for Developing Nations. Toim Joan Rubin, B. Jernudd. Honolulu: University of Hawaii Press, lk 195-215

J offé, George H. 2007. Foreword. Regionalism a New Paradigm? - European Union and New Regionalism: Regional Actors and Global Governance in a PostHegemonic Era. 2. tr. Toim Mario Telò. Burlington, VT: Ashgate, lk xiii-xvii.

Jør g e n s e n, J. Normann 2010. Languaging: Nine Years of Poly-lingual Development of Young Turkish-Danish Grade School Students. Kd 1-2. Copenhagen: University of Copenhagen.

Ka plins ki, Jaan 1985. Õhtu toob tagasi kõik. Tallinn: Eesti Raamat.

Kattel, Rainer, Thor halls s o n, Baldur 2013. Neo-liberal small states and economic crisis: Lessons for democratic corporatism. - Journal of Baltic Studies, kd 44, nr 1, lk 83-105.

Kir by, David G. 1995. The Baltic World 1772-1993: Europe's Northern Periphery in an Age of Change. London: Longman.

Kl a a s - L a ng, Birute 2016. State policies and institutional language choice - the vitality of Estonian, Latvian and Lithuanian in higher education. - Sociolinguistic Transition in Former Soviet and Eastern Bloc Countries: Recent Developments Two Decades after the Regime Change. Toim Marian Sloboda, Petteri Laihonen, Anastassia Zabrodskaja. Prague: Peter Lang Verlag, lk 235-262.

Korkut, Umut 2008. Eager, Pragmatic or Reluctant: Can common Finno-Ugric ethnic and linguistic links substantiate intra-EU CFSP co-operation? (CASE Network Studies and Analyses, 367.) Warsaw: Center for Social and Economic Research.

Ku 11, Kalevi, Lang, Valter 2015. Piiride rikkus ja muutuste mustrid. - Sirp 23. I. http://www.sirp.ee/s1-artiklid/c9-sotsiaalia/piiride-rikkus-ja-muutuste-mustrid/ (1. VIII 2017). 
Ku r s, Ott 1998. Arvustus: Tagasi Läände? Return to the Western World. Cultural and Political Perspectives on the Estonian Post-Communist Transition. Edited by Marju Lauristin \& Peeter Vihalemm with Karl Erik Rosengren \& Lennart Weibull. Tartu University Press, 1997. - Akadeemia, nr 3, lk 628-630.

Kährik, Anneli 2006. Socio-spatial Residential Segregation in Post-Socialist Cities: The Case of Tallinn. (Dissertationes Geographicae Universitatis Tartuensis 29.) Tartu: Tartu Ülikooli Kirjastus.

Liddicoat, Anthony 2013. Language-in-Education Policies: The Discursive Construction of Intercultural Relations. Bristol: Multilingual Matters.

Light, Matthew 2010. Policing Migration in Soviet and post-Soviet Moscow. Post-Soviet Affairs, kd 26, nr 4, lk 275-313.

Lin, Angel, Martin, Peter 2005. Decolonisation, Globalisation. Language-inEducation Policy and Practice. Clevedon: Multilingual Matters.

May, Stephen 2015. The problem with English(es) and linguistic (in)justice. Addressing the limits of liberal egalitarian accounts of language. - Critical Review of International Social and Political Philosophy, kd 18, nr 2, lk 131-148.

M c C arty, Teresa L. (toim) 2011. Ethnography and Language Policy. New York: Routledge.

Pavlenko, Aneta 2013. Multilingualism in post-Soviet successor states. - Language and Linguistic Compass, kd 7, nr 3, lk 262-271.

Pawłusz, Emilia 2017. The Estonian song celebration (Laulupidu) as an instrument of language policy. - Journal of Baltic Studies, kd 48, nr 2, lk 251-271.

Peled, Yael, Ives, Peter, Ricento, Thomas 2014. Introduction to the thematic issue: Language policy and political theory. - Language Policy, kd 13, nr 4, lk 295-300.

Petrovic, John E. 2015. A Post-Liberal Approach to Language Policy in Education. Bristol: Multilingual Matters.

Pettai, Vello 2007. The construction of state identity and its legacies: Legal restorationism in Estonia. - Ab Imperio, nr 3, lk 403-426.

Piattoni, Simona 2009. Multi-level governance: A historical and conceptual analysis. - European Integration, $\mathrm{kd} 31$, nr 2, lk 163-180.

$\mathrm{P}$ ä äb o, Heiko 2014. Constructing historical space: Estonia's transition from the Russian civilization to the Baltic Sea region. - Journal of Baltic Studies, kd 45, nr 2, lk 187-205.

R a n n u t, Mart 2017. Eesti keele õiguslik ja tegelik staatus tööturul. - Eesti inimarengu aruanne 2016/2017. Eesti rändeajastul. Peatoim Tiit Tammaru. Tallinn: Eesti Koostöö Kogu, lk 195-201. https://inimareng.ee (1. VIII 2017).

Rannut, Mart, Rannut, Ülle 2010. Russification of non-Estonian pupils in Tallinn. - Eesti Rakenduslingvistika Ühingu aastaraamat, nr 6, lk 243-259.

Ricento, Thomas K., Horn berger, Nancy H. 1996. Unpeeling the onion: Language planning and policy and the ELT professional. - TESOL Quarterly, kd 30, nr 3, lk 401-427.

Ryaz an ova-Clarke, Larissa 2014. Russian with an accent: Globalization and the post-Soviet imaginary. - The Russian Language Outside the Nation. Toim L. Ryazanova-Clarke. Edinburgh: Edinburgh University Press, lk 249-280.

S a a r t s, Tõnis 2017. XXI sajandi poliitikud. - Sirp 16. VI.

Sh o h a my, Elana 2006. Language Policy: Hidden Agendas and New Approaches.

London: Routledge. 
Shore, Cris, Wright, Susan (toim) 1997. Anthropology of Policy: Critical Perspectives on Governance and Power. London-New York: Routledge.

Siiner, Maarja, Koreinik, Kadri, Brown, Kara D. (toim) 2017. Language Policy Beyond the State. Springer.

Skerrett, Delaney Michael 2014. The Estonian 2011 high school reform in the context of critical language policy. - Current Issues in Language Planning, $\mathrm{kd}$ 15, nr 2, lk 174-200.

Soler-Carbonell, Josep, Sa arinen, Taina, Kibbermann, Kerttu 2017. Multilayered perspectives on language policy in higher education: Finland, Estonia, and Latvia in comparison. - Journal of Multilingual and Multicultural Development, kd 38, nr 4, lk 301-314.

Sk o c pol, Theda 1985. Introduction. - Bringing the State Back In. Toim Peter B. Evans, Dietrich Rueschemeyer, T. Skocpol. Cambridge: Cambridge University Press, lk 3-38.

Sonntag, Selma K., Cardinal, Linda 2015. State traditions and language regimes: A historical institutionalism approach to language policy. - Acta Universitatis Sapientiae, European and Regional Studies, kd 8, nr 1, lk 5-21.

Spolsky, Bernard 2004. Language Policy. Cambridge: Cambridge University Press.

StatFin. Population. Population Structure. 010 -- Language according to age and sex by region in 1990 to 2016. http://pxnet2.stat.fi/PXWeb/pxweb/ en/StatFin/StatFin__vrm__vaerak/statfin_vaerak_pxt_010.px/table/ tableViewLayout1/?rxid=f50e33c9-eccb-46d2-b64d-dba4dbed4d1b (29. VIII 2017).

$\mathrm{Z}$ agr e be n, Alexey 2007. The scientist and authority in the history of Finno-Ugric research in Russia. - Journal of Ethnology and Folkloristics, kd 1, nr 1, lk 63-73.

T a a g e per a, Rein 1998. Arvustus: Tagasi Läände? Return to the Western World. Cultural and Political Perspectives on the Estonian Post-Communist Transition. Edited by Marju Lauristin \& Peeter Vihalemm with Karl Erik Rosengren \& Lennart Weibull. Tartu University Press, 1997. - Akadeemia, nr 3, lk 626-628.

$\mathrm{T}$ a $\mathrm{m} \mathrm{m}$ a r u, Tiit 2001. The Soviet Union as a deviant case? Underurbanization in Soviet Estonia. - Urban Geography, kd 22, nr 6, lk 584-603.

Tammaru, Tiit, Kumer-Haukanõmm, Kaja, Anniste, Kristi 2010. The formation and development of the Estonian diaspora. - Journal of Ethnic and Migration Studies, kd 36, nr 7, lk 1157-1174.

Tollefs o n, James W. 1991. Planning Language, Planning Inequality. New York: Longman.

Tollefs on, James, W., Pére z-Milans, Miguel (toim) 2017. The Oxford Handbook of Language Policy and Planning. Oxford: Oxford University Press.

To o met, Ott, Silm, Siiri, Saluve er, Erki, Ahas, Rein, T a m m a r u, Tiit 2015. Where do ethno-linguistic groups meet? How copresence during free-time is related to copresence at home and at work. - PLoS ONE, kd 10, nr 5, lk 1-16.

van Ham, Maarten, Tam maru, Tiit 2016. New perspectives on ethnic segregation over time and space: A domains approach. - Urban Geography, kd 37, nr 7, lk 953-962.

Ver s chik, Anna 2017. Ränne, identiteedi ja keelemuutused. - Eesti inimarengu aruanne 2016/2017. Eesti rändeajastul. Peatoim Tiit Tammaru. Tallinn: Eesti Koostöö Kogu, lk 166-169. https://inimareng.ee (1. VIII 2017). 
Vetik, Raivo (toim) 2012. Nation-Building in the Context of Post-Communist Transformation and Globalization. Frankfurt am Main: Peter Lang Verlag.

Vihale m m, Triin, Hog a - Brun, Gabrielle 2013. Language policies and practices across the Baltic: Processes, challenges and prospects. - European Journal of Applied Linguistics, kd 1, nr 1, lk 55-82.

Wright, Sue 2004. Language Policy and Planning: From Nationalism to Globalisation. Basingstoke: Palgrave Macmillan.

\section{Should the state be the only focus of language-policy research?}

Keywords: language policy and planning (LLP), language, policy, state, globalization, Estonia

The article examines, and questions, the centering of the state as the primary language policy actor particularly in the context of Estonia. In responding to several paradigmatic shifts in the field of language policy and planning, including a critical turn that shifted researchers' attention to language users, the authors explore the multiple expressions of language policy and introduce language policy actors other than the state. The article opens with an introduction to the core concepts of language, policy, and state with attention to the multiple interpretations and examples that challenge current understandings of these ideas. The authors then turn to present the case for an Estonian focus. First, Estonia is situated on multiple borders - geopolitical and linguistic among others (resulting in the country's rich language ecology) - that reflect political and migratory shifts over time. Second, Estonia represents a case of dynamic state-building. From the enduring commitment to being "European" to legal restorationism and neoliberal economic policies, language policies are developed in a multifaceted, changing context. The article then presents a fresh focus on language policy and Estonia by moving beyond the past, dominating foci of research on the temporal border which either fixed Estonia in a post-Soviet, Baltic, and European Union frame or tethered it to a singular development, particularly to "solving" the Russian problem. While these frames dominate research, other geographic imaginaries, like the Baltic Sea Region, lend themselves to a redrawing of the lines and influence of the language-policy power of the state. The authors also examine the powerful decentering of the state in language policy through attention to globalization, migration, and regionalization. Finally, the article explores the enduring ways the Soviet "covert" language policies continue to shape contemporary Estonian language policies.

Kadri Koreinik (b. 1970), PhD, University of Tartu, Institute of Estonian and General Linguistics, Department of Estonian, Senior Research Fellow; Researcher at Võru Institute, kadri.koreinik@ut.ee

Kara D. Brown (b. 1973), PhD, University of South Carolina, Department of Educational Studies, Associate Professor, Visiting Research Fellow at the University of Tartu,brownk25@mailbox.sc.edu

Maarja Siiner (b. 1973), PhD, University of Oslo, Center for Multilingualism in Society across the Lifespan (MultiLing), Research Affiliate; Aarhus University, Department of Linguistics, Cognitive Science and Semiotics, maarja@siiner.eu 